\title{
Diatom-oxygen isotope record from high-altitude Lake Petit (2200 m a.s.I.) in the Mediterranean Alps: shedding light on a climatic pulse at $4.2 \mathrm{ka}$
}

\author{
Rosine Cartier ${ }^{1,2,5}$, Florence Sylvestre ${ }^{1}$, Christine Paillès ${ }^{1}$, Corinne Sonzogni ${ }^{1}$, Martine Couapel ${ }^{1}$, Anne Alexandre ${ }^{1}$, \\ Jean-Charles Mazur ${ }^{1}$, Elodie Brisset ${ }^{3,4}$, Cécile Miramont ${ }^{2}$, and Frédéric Guiter ${ }^{2}$ \\ ${ }^{1}$ Aix-Marseille University, CNRS, IRD, Collège de France, INRA, CEREGE, Europôle de l'Arbois, \\ 13545 Aix-en-Provence, France \\ ${ }^{2}$ Aix-Marseille University, CNRS, IRD, Avignon University, IMBE, Europôle de l'Arbois, 13545 Aix-en-Provence, France \\ ${ }^{3}$ IPHES, Institut Català de Paleoecologia Humana i Evolució Social, Tarragona, Spain \\ ${ }^{4}$ Àrea de Prehistòria, Universitat Rovira i Virgili, Tarragona, Spain \\ ${ }^{5}$ Lund University, Department of Geology, Lund, Sweden
}

Correspondence: Rosine Cartier (rosine.cartier@geol.lu.se)

Received: 15 August 2018 - Discussion started: 3 September 2018

Accepted: 30 December 2018 - Published: 7 February 2019

\begin{abstract}
In the Mediterranean area, the $4.2 \mathrm{ka} \mathrm{BP}$ event is recorded with contrasting expressions between regions. In the southern Alps, the high-altitude Lake Petit (Mercantour Massif, France; $2200 \mathrm{~m}$ a.s.l.) offers pollen and diatom-rich sediments covering the last 4800 years. A multi-proxy analysis recently revealed a detrital pulse around $4200 \mathrm{cal}$ BP due to increasing erosion in the lake catchment. The involvement of a rapid climate change leading to increasing runoff and soil erosion was proposed. Here, in order to clarify this hypothesis, we measured the oxygen isotope composition of diatom silica frustules $\left(\delta^{18} \mathrm{O}_{\text {diatom }}\right)$ from the same sedimentary core. Diatoms were analysed by laser fluorination isotope ratio mass spectrometry after an inert gas flow dehydration. We additionally enhanced the accuracy of the agedepth model using the Bacon $\mathrm{R}$ package. The $\delta^{18} \mathrm{O}_{\text {diatom }}$ record allows us to identify a 500-year time lapse, from 4400 to $3900 \mathrm{cal} \mathrm{BP}$, where $\delta^{18} \mathrm{O}_{\text {diatom }}$ reached its highest values $\left(>31 \%\right.$ o). $\delta^{18} \mathrm{O}_{\text {diatom }}$ was about $3 \%$ higher than the modern values and the shifts at 4400 and $3900 \mathrm{cal} \mathrm{BP}$ were of similar amplitude as the seasonal $\delta^{18} \mathrm{O}_{\text {diatom }}$ shifts occurring today. This period of high $\delta^{18} \mathrm{O}_{\text {diatom }}$ values can be explained by the intensification of ${ }^{18} \mathrm{O}$-enriched Mediterranean precipitation events feeding the lake during the ice-free season. This agrees with other records from the southern Alps suggesting runoff intensification around $4200 \mathrm{cal} \mathrm{BP}$. Possible changes in other climatic parameters may have played a concomi-
\end{abstract}

tant role, including a decrease in the contribution of ${ }^{18} \mathrm{O}$ depleted Atlantic winter precipitation to the lake water due to snow deficit. Data recording the $4.2 \mathrm{ka} \mathrm{BP}$ event in the northwestern Mediterranean area are still sparse. In the Lake Petit watershed, the $4.2 \mathrm{kaBP}$ event translated into a change in precipitation regime from 4400 to $3900 \mathrm{cal}$ BP. This record contributes to the recent efforts to characterize and investigate the geographical extent of the $4.2 \mathrm{ka} \mathrm{BP}$ event in the Mediterranean area.

\section{Introduction}

Since the last glaciation, several abrupt climatic changes, with large environmental effects, were identified from palaeoclimatic records (Berger and Guilaine, 2009; Magny et al., 2009), such as the Younger Dryas (13 500-11 $500 \mathrm{cal} \mathrm{BP})$ at the end of the Late Glacial and the $8.2 \mathrm{ka}$ event at the beginning of the Holocene (Alley et al., 1997; Brauer et al., 1999; Tinner and Lotter, 2001), for the coldest events. Other Holocene climatic events were described as less intense or regionally limited but may have triggered substantial impacts on the environment at the local scale. One of them, the "4.2 ka BP event", was recognized as an abrupt climate change (Bond et al., 1997; Booth et al., 2005; Huang et al., 2011; Thompson et al., 2002; Staubwasser et al., 2003) 
and is now commonly used as a marker of Holocene stratigraphy (Walker et al., 2012). In the Mediterranean area, the $4.2 \mathrm{ka} \mathrm{BP}$ event is recorded with contrasting expressions between regions (Bruneton et al., 2002; Digerfeldt et al., 1997; Drysdale et al., 2006; Kharbouch, 2000; Magny et al., 2009; Miramont et al., 2008; Zanchetta et al., 2011). In the eastern Mediterranean area, this climatic event is assumed to have been responsible for severe droughts and involved in the fall of the Akkadian civilization (Weiss et al., 1993; Cullen et al., 2000; Dean et al., 2015). In the central Mediterranean area, speleothem isotope records suggest a reduction in cave recharges from ca. $4500 \mathrm{cal} \mathrm{BP}$ to $4100 \mathrm{cal} \mathrm{BP}$ at Corchia Cave (Isola et al., 2019) and ca. 4500 cal BP to $4100 \mathrm{cal} \mathrm{BP}$ at Renella Cave (Zanchetta et al., 2016), linked to annual and/or winter dry conditions. In the Alps (northern Italy), an opposite trend has been described, annual cool and wet conditions being assigned to the period around $4.2 \mathrm{ka}$ (Magny et al., 2012; Zanchetta et al., 2016). Sedimentary records of past lake levels also mirror different climatic expression between regions. At Lake Ledro and Lake Accesa, in Italy, the transition from mid- to late Holocene surrounding $4.2 \mathrm{ka}$ shows a shift from low to high lake levels. Pollen-based precipitation reconstructions, although showing high variability from 5000 to $3000 \mathrm{cal} \mathrm{BP}$, suggest no significant change in the amount of annual precipitation but increasing summer precipitation (Peyron et al., 2013). The high-resolution record from Lake Accesa (Italy) allowed us to interpret the 4.2 ka BP climatic event as a tripartite climatic oscillation with a phase of drier conditions from 4100 to $3950 \mathrm{cal}$ BP bracketed by two phases of wetter conditions (Magny et al., 2009). Overall, palaeoclimatic records from the Mediterranean area highlight climatic features spatially heterogeneous around $4200 \mathrm{cal} \mathrm{BP}$, which makes it difficult to assign a general pattern. Further studies from different geomorphological contexts are required for a better characterization of the $4.2 \mathrm{ka} \mathrm{BP}$ climatic event in the area.

In the southern Alps, the high-altitude Lake Petit (Mercantour Massif, France; $2200 \mathrm{~m}$ a.s.1.) offers pollen and diatomrich sediments covering the last 5000 years. A multi-proxy analysis, including sedimentological and geochemical measurements, pollen and diatom morphological analyses, revealed a detrital pulse around $4200 \mathrm{cal}$ BP due to increasing erosion in the lake catchment (Brisset et al., 2012, 2013), followed by an abrupt change in diatom assemblages. The replacement of the dominant diatom Staurosirella pinnata by Pseudostaurosira spp. responded to a change in lacustrine living conditions (e.g. nutrient availability, turbidity) following the detrital input (Cartier et al., 2015). The hypothesis of a massive deforestation in the catchment to explain the detrital pulse was rejected as the vegetation surrounding the lake stayed open over the last 5000 years. Therefore, the involvement of a rapid change either in precipitation regime or temperature, leading to increasing soil erosion and runoff around $4200 \mathrm{cal} \mathrm{BP}$, was proposed (Brisset et al., 2012, 2013; Cartier et al., 2015).
Here, in order to clarify this hypothesis, we measured the oxygen isotope composition of diatom silica frustules $\left(\delta^{18} \mathrm{O}_{\text {diatom }}\right)$ from the Lake Petit sedimentary core previously used for the multi-proxy analyses and covering the last 5000 years (Brisset et al., 2013). $\delta^{18} \mathrm{O}_{\text {diatom }}$ records are commonly used for paleoclimatic reconstructions (e.g. Barker et al., 2001; Leng and Barker, 2006; Quesada et al., 2015). The $\delta^{18} \mathrm{O}_{\text {diatom }}$ value is controlled by the lake water isotope composition $\left(\delta^{18} \mathrm{O}_{\text {lake }}\right)$ and the temperature of silica polymer-

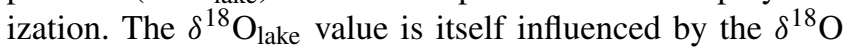
signatures of precipitation $\left(\delta^{18} \mathrm{O}_{\text {precipitation}}\right)$ and other waters reaching and leaving the lake (groundwater, surface water) and the extent of the lake water evaporation. Lastly, the $\delta^{18} \mathrm{O}_{\text {precipitation }}$ is controlled by the isotope composition of its water vapour source and Rayleigh fractionation processes occurring during the vapour transport and rain drop formation. Changes in Lake Petit $\delta^{18} \mathrm{O}_{\text {diatom }}$ values are discussed according to these parameters, and assumptions characterizing the abrupt climate change that may have occurred around $4200 \mathrm{cal}$ BP in the lake catchment area, and more broadly in the southern Alps, are presented.

\section{Site settings}

Lake Petit (2200 m a.s.1.; $44^{\circ} 06.789 \mathrm{~N}, 7^{\circ} 11.342 \mathrm{E}$ ) is a small circular body of water, $150 \mathrm{~m}$ in diameter, located in the southern French Alps about $60 \mathrm{~km}$ from the Mediterranean Sea. The $6 \mathrm{~km}^{2}$ lake catchment culminates at $2600 \mathrm{~m}$ a.s.l. It is composed of crystalline bedrock (gneiss and migmatites) and is largely covered by alpine meadows. The upper tree line (Larix sp.) is located at about $2100 \mathrm{~m}$ a.s.l. Lake Petit is at the lowest elevation of a chain of five lakes that were partly formed by glacier retreat (Fig. 1). The five lakes are connected in spring during meltwater but remain unconnected for the rest of the year. The lake surface is usually frozen from October to April. The water depth of Lake Petit reaches $7 \mathrm{~m}$ in the wake of the snowmelt and is about $1 \mathrm{~m}$ lower at the end of summer. The lake is open during snowmelt but has no outlet during summer. Water inputs are thus represented by snowmelt in spring and precipitation during the ice-free season. Water outputs mainly consist of evaporation, infiltration likely being very low due to the geological characteristics of the catchment. Today, diatoms are mainly benthic but tychoplanktonic diatoms are also present. These diatoms develop mainly during the ice-free season, even if some species (e.g. Achnanthes, Fragilaria spp.) are expected to continue to grow under the ice during winter as observed in other alpine lakes (Lotter and Bigler, 2000).

In the Mercantour Massif, alpine and mediterranean influences produce a climate marked by mild winters and dry summers. Mean annual air temperature at $1800 \mathrm{~m}$ a.s.l. is $5^{\circ} \mathrm{C}$, varying from $0.3^{\circ} \mathrm{C}$ in winter to $9.9^{\circ} \mathrm{C}$ in summer. Mean annual precipitation is $1340 \mathrm{~mm}$ at $1800 \mathrm{~m}$ a.s.l. Snow depths in winter are relatively important $(150$ to $250 \mathrm{~cm}$ at 

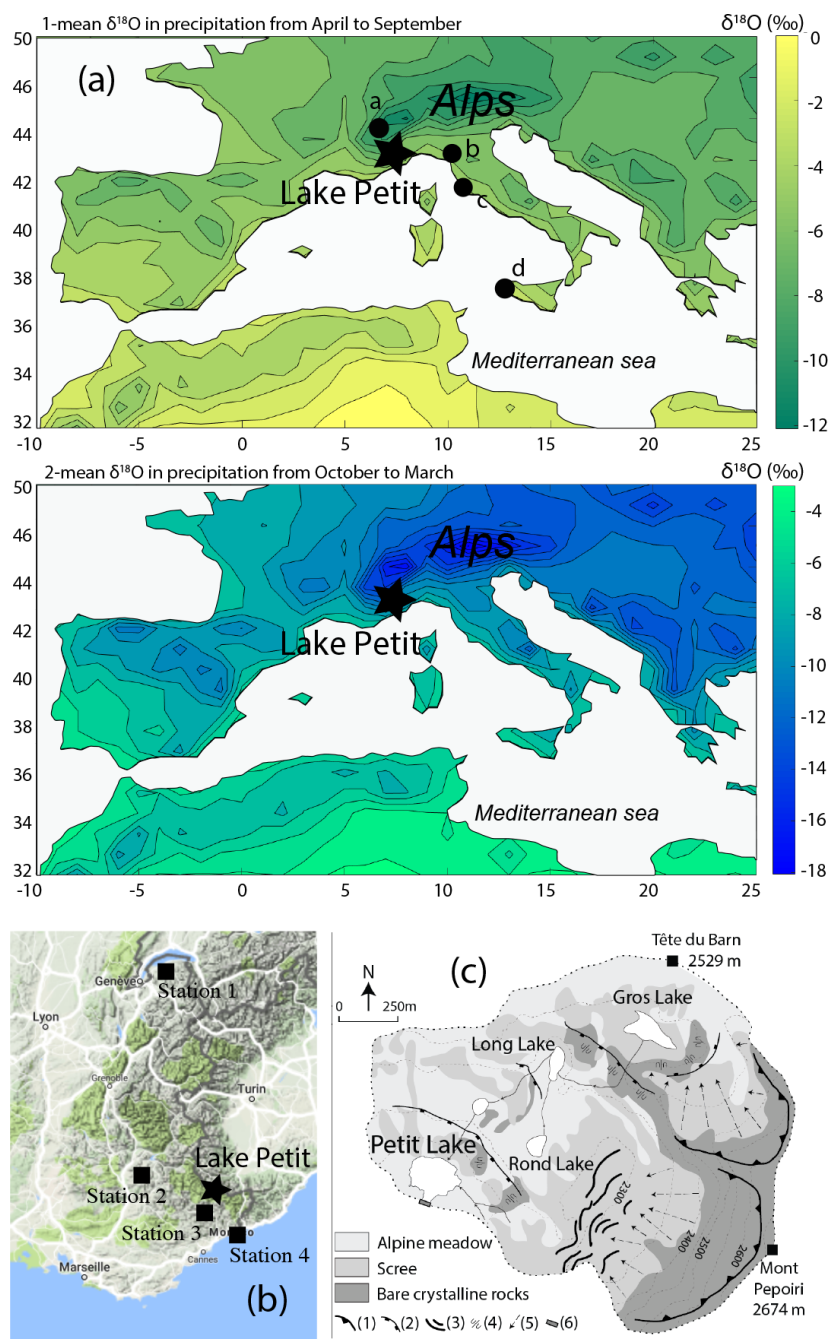

Figure 1. Localization map of Lake Petit: (a) mean $\delta^{18} \mathrm{O}$ in precipitation $\left(\delta^{18} \mathrm{O}_{p}\right)$ (in \%o vs. V-SMOW) in the western Mediterranean region (IAEA/WMO, 2018; period 1960-2009) and selected palaeoclimatic studies: a - Ecrins-Pelvoux Massif (Le Roy et al., 2017); b - Buca della Renella (Zanchetta et al., 2016); c - Accesa Lake (Magny et al., 2009); d - Preola Lake (Magny et al., 2012). (b) GNIP (Global Networks of Isotopes in Precipitation) stations (IAEA/WMO, 2018) in black squares: (1) Thonon-les-bains, (2) Draix, (3) Malaussène, (4) Monaco. (c) Watershed characteristics: (1) glacial cirque, (2) glacial step, (3) moraine, (4) polished bedrock, (5) active debris slope, (6) dam built in 1947.

$2400 \mathrm{~m}$ a.s.l.) and snow cover duration is about 185 days at $2100 \mathrm{~m}$ a.s.l. mainly from November to April (Durand et al., 2009a, b). Because it is located in the extreme south-western part of the Alps, Lake Petit is strongly influenced by precipitation originating from the Mediterranean region during the summer, while winter snowfalls are essentially associated with north-west Atlantic atmospheric flows (Bolle, 2003; Lionello et al., 2006, 2012). In southern France, precipitation is mostly generated by the clash between the warm, humid air of Mediterranean or mixed Atlantic-Mediterranean origin and cool air masses coming from the north. Today, $54 \%$ of precipitation in southern France (average for six meteorological stations) strictly come from the Mediterranean area, $12 \%$ from the Atlantic and $34 \%$ have a mixed Mediterranean-Atlantic influence (Celle-Jeanton, 2001). In spring and autumn the advection of air masses from the Mediterranean can produce strong storms. Altogether, the Mediterranean influence remains predominant today, with

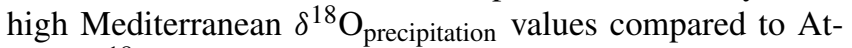

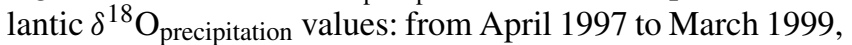
at Avignon (IAEA/WMO, $43^{\circ} 57 \mathrm{~N}$ ) precipitation of Mediterranean origin had a weighted annual mean $\delta^{18} \mathrm{O}_{\text {precipitation }}$ of $-4.33 \%$ ( $\mathrm{SD}=1.72 \%$ ), whereas precipitation from the Atlantic had a $\delta^{18} \mathrm{O}_{\text {precipitation of }-8.48 \% \text { ( }} \mathrm{SD}=3.51 \%$ ) (Celle-Jeanton et al., 2004). Added to changes in temperature, changes in precipitation sources explain the cur-

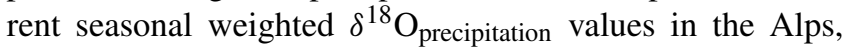
lower from October to March than from April to September (Fig. 1, period 1960-2009; IAEA/WMO, 2018; Terzer et al., 2013). Different precipitation sources also explain the $\delta^{18} \mathrm{O}_{\text {precipitation values obtained for the same period at }}$ the meteorological stations close to Lake Petit (Fig. 2a; IAEA/WMO, 2018).

\section{Material and methods}

Sediment core PET09P2 (144 cm long) was sampled in 2009 in the deepest part of the lake using a UWITEC gravity corer. Core PET09P2 is organic-rich (total organic carbon represents $9 \%$ of the dry weight on average), and biogenic silica is abundant (averaging $65 \%$ of the dry weight) (Brisset et al., 2013). The core is composed of homogeneous yellow to greenish diatomaceous sediments with millimetrethick brownish diatom-clay laminations. The sediments consist of biogenic silica (diatoms), organic compounds (essentially algal as the hydrogen index comprised between 450 and $575 \mathrm{HC}$ (hydrocarbon) / TOC (total organic carbon) and a terrigenous clay fraction (Brisset et al., 2012, 2013). The different lithological units are presented in Fig. 4. Diatoms (D) represent the major contribution of biogenic silica in the sedimentary record. Only a few cysts of Chrysophyceae (C) were identified $(C / D$ ratio $=0.01)$. The age-depth model covering the last 4800 years is based on short-lived ${ }^{210} \mathrm{~Pb}$ and ${ }^{137} \mathrm{Cs} \mathrm{ra-}$ dionuclide data and seven ${ }^{14} \mathrm{C}$ ages obtained from terrestrial macro-remains (Brisset et al., 2013, for further details). For this study, we recalculated the age-depth model using the Bacon R package (Blaauw and Christen, 2011) and implemented the function proxy.ghost (square resolution: 200) in order to highlight the chronological uncertainties of the agedepth model and to estimate the duration of the $4.2 \mathrm{kaBP}$ event recorded at Lake Petit. Figure $3 \mathrm{~b}$ shows a range of possible ages for each sample depth.

Twenty diatom samples $\left(1 \mathrm{~cm}^{3}\right)$ were subsampled from core PET09P2. Each diatom sample includes on average 

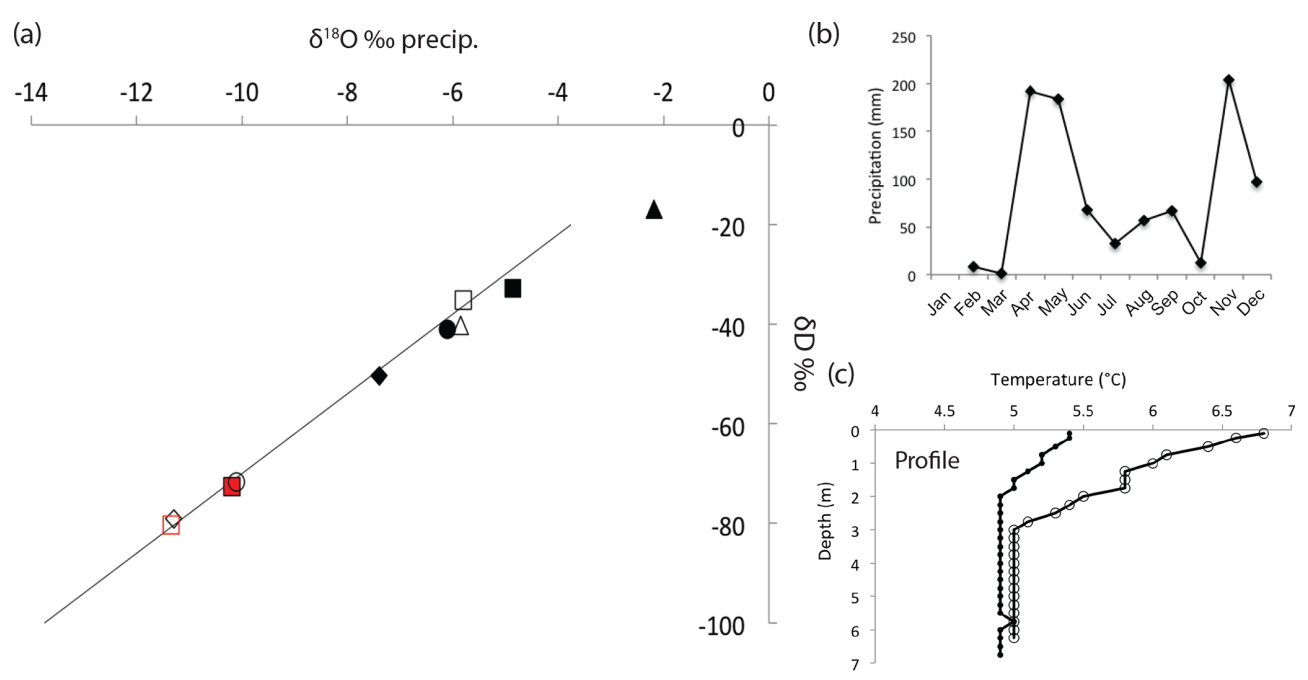

Figure 2. (a) $\delta^{18} \mathrm{O} p$ (in \%o vs. V-SMOW) from GNIP stations (IAEA/WMO, 2018) and from Lake Petit (in red) at two key times of the year (empty red square - 17 May 2011; full red square - 17 September 2011) plotted across the global meteoric water line (black line). Locations of GNIP stations are shown in Fig. 1. Mean weighted average of $\delta^{18} \mathrm{O} p$ for each station is represented by black filled markers for summer months (April to September) and black empty markers for winter months (October to March): Thonon-les-bains (black diamonds), Malaussène (white squares), Monaco (black triangles), Draix (black circles). (b) Average annual distribution of precipitation (mm) at the meteorological station Malaussène by month for the year 1997 and 1998; no data for the month of January (IAEA/WMO, 2018). (c) Profile of water temperature $\left({ }^{\circ} \mathrm{C}\right)$ as a function of water depth $(\mathrm{m})$ in Lake Petit at two locations on 17 May 2012.

36 years (min: 11 years; max: 55 years) of sedimentation according to the age-depth model. Diatom samples were weighed after drying at $50^{\circ} \mathrm{C}$. To remove carbonates and organic matter, the samples were first treated using standard procedures (bathed in a 1:1 mixture of $33 \% \mathrm{H}_{2} \mathrm{O}_{2}$ : water, a $1: 1$ mixture of $10 \% \mathrm{HCl}$ : water, and repeatedly rinsed in distilled water). Following these steps, the identification and counting of diatom species for palaeoenvironmental reconstruction were performed. The data were reported in Cartier et al. (2015). Then, diatom silica frustules were cleaned from remaining detrital particles by following a protocol based on chemical oxidation and densimetric separation previously detailed in Crespin et al. (2008). The purity of each sample was checked using optical and scanning electron microscopy (SEM). Micro-X-ray fluorescence (XRF) measurements (five measurements per sample) were additionally made using a HORIBA XGT-5000177 microscope equipped with an Xray guide tube capable of producing a focused, high-intensity beam with a $100 \mu \mathrm{m}$ spot size (detection limit: $2 \mathrm{ppm}$ ). The following compounds were detected via XRF: $\mathrm{SiO}_{2}, \mathrm{Al}_{2} \mathrm{O}_{3}$, $\mathrm{K}_{2} \mathrm{O}, \mathrm{CaO}, \mathrm{TiO}_{2}, \mathrm{Fe}_{2} \mathrm{O}_{3}$ and $\mathrm{Br}_{2} \mathrm{O}$. The samples are on average composed of $97.2 \%(\mathrm{SD}=1.8 \%)$ of $\mathrm{SiO}_{2}$.

Measurements of oxygen isotopes from diatoms were performed at the CEREGE Stable Isotope laboratory (Aix-enProvence, France). The samples were dehydrated and dehydroxylated under a flow of $\mathrm{N}_{2}$ (Chapligin et al., 2010). Oxygen extraction was performed using the infrared (IR) laser-heating fluorination technique (Alexandre et al., 2006; Crespin et al., 2008). No ejection occurred during the analysis. The oxygen gas samples were sent directly to and analysed by a dual-inlet mass spectrometer (ThermoQuest Finnigan Delta Plus). Measured $\delta^{18} \mathrm{O}$ values were corrected on a daily basis using a quartz lab standard $\left(\delta^{18} \mathrm{O}_{\text {Boulangé }} 50-100 \mu \mathrm{m}\right)$ calibrated on NBS28 $(9.6 \pm 0.3 \%$; $n=11)$. The values are expressed in the standard $\delta$ notation relative to V-SMOW. The long-term precision of the quartz lab standard is $\pm 0.2 \%$ o $(1 \mathrm{~s} ; n=50)$. The $\delta^{18} \mathrm{O}_{\text {diatom val- }}$ ues presented here are averages of two replicates. The reproducibility was better than $\pm 0.2 \%$.

Two surficial lake water samples were collected in the first metres of depth in spring (17 May 2011) after the snowmelt, and at the end of the summer (17 September 2011). They were analysed for $\delta^{18} \mathrm{O}$ and $\delta \mathrm{D}$ by isotope ratio mass spectrometry (IRMS) and the data were normalized on the VSMOW (Vienna Standard Mean Ocean Water)/SLAP (Standard Light Antarctic Precipitation) scale. The values are expressed in the standard $\delta$ notation relative to V-SMOW. Temperature in the water column was measured in spring (17 May 2012) at two locations $\left(44^{\circ} 1133 \mathrm{~N}, 7^{\circ} 1894 \mathrm{E}\right.$; $44^{\circ} 1134 \mathrm{~N}, 7^{\circ} 1889 \mathrm{E}$ ), every $25 \mathrm{~cm}$, down to the bottom of the lake.

\section{Results}

The $\delta^{18} \mathrm{O}$ and $\delta \mathrm{D}$ compositions of the sampled lake water were $-11.35 \%$ and $-80.36 \%$, respectively, after the snowmelt and $-10.19 \%$ and $-72.6 \%$, respectively, at the end of summer 2011. They plot on the global meteoric water line (Fig. 2a). The distribution of precipitation over the 

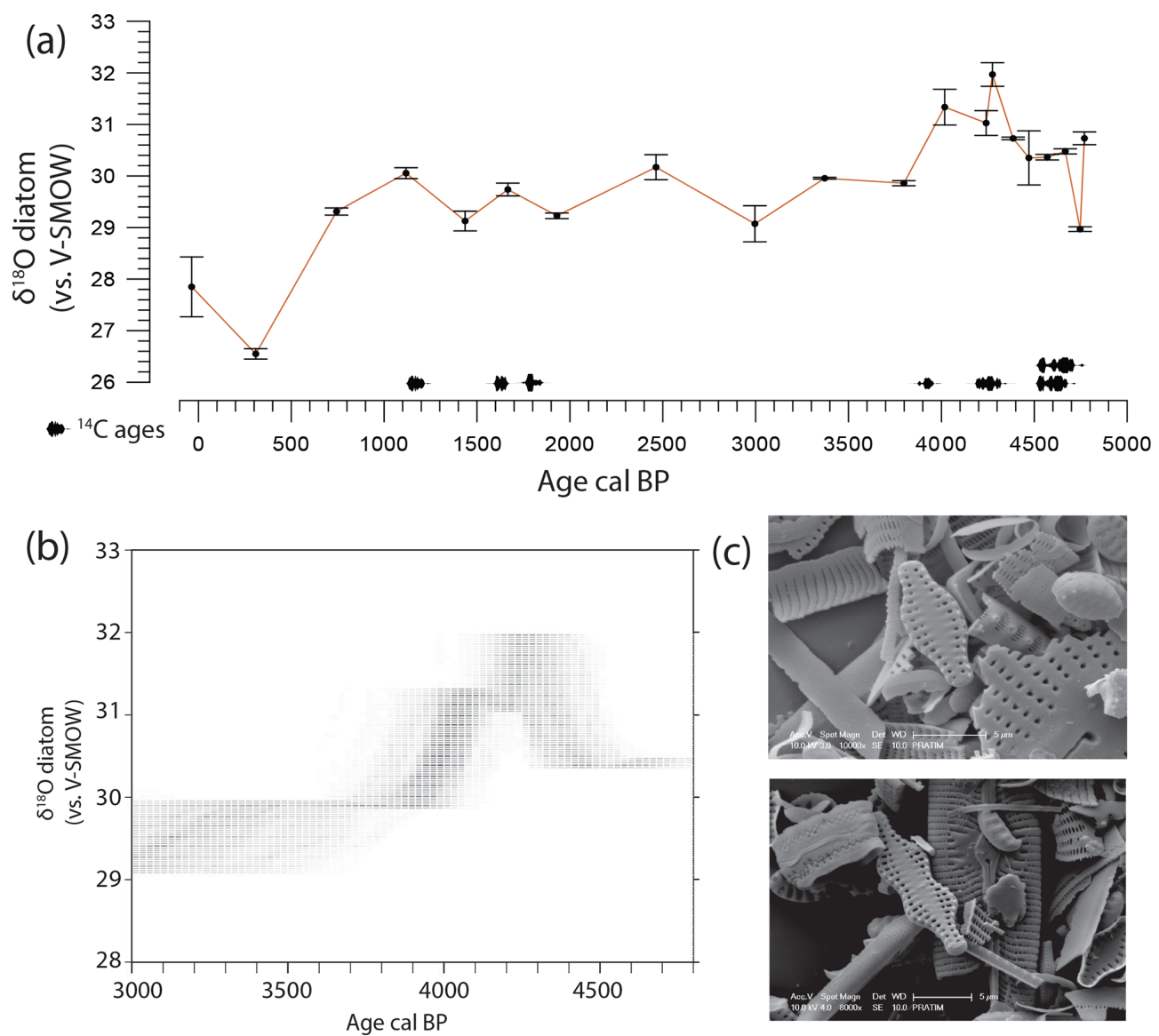

Figure 3. (a) Oxygen isotope composition of diatoms ( $\delta^{18} \mathrm{O}$ diatom expressed in $\%$ vs. V-SMOW) from Lake Petit sediments; (b) $\delta^{18} \mathrm{O}$ diatom (vs. V-SMOW) taking into account the age uncertainties (the darkest grey is assigned to the most likely value within the entire core (normalized to 1); lower age probabilities are coloured in lighter grey); (c) SEM image of a cleaned diatom sample from $127 \mathrm{~cm}$ depth using a scanning electron microscope.

year at the closest meteorological station to Lake Petit is presented in Fig. 2b (station Malaussène, period 1997-1998; IAEA/WMO, 2018). Water temperature measured at two points of Lake Petit in 17 May 2012 varied from 5.4 to $4.9^{\circ} \mathrm{C}$ and from 6.8 to $5{ }^{\circ} \mathrm{C}$ (from surface to bottom) (Fig. 2c).

Because the dissolution of the diatom frustules during sedimentation may occur and induce kinetic isotope fractionation (Dodd et al., 2017), the samples were checked under SEM. The diatoms themselves were very well preserved. No significant dissolution features were observed, as shown in Fig. 3c.

$\delta^{18} \mathrm{O}_{\text {diatom }}$ values measured on the 20 sedimentary diatom samples (Table 1) are plotted against ages (cal BP) and

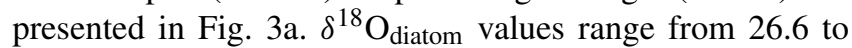
$32 \%$ with a mean standard deviation (SD) of $0.18 \%$. From the bottom of the core $(4800 \mathrm{cal} \mathrm{BP})$ to $4400 \mathrm{cal} \mathrm{BP}$, the $\delta^{18} \mathrm{O}_{\text {diatom }}$ average value is $30.3 \% \circ \pm 0.14 \%$ and the lowest value $(28.97 \%$ o occurs at $4750 \mathrm{cal}$ BP. Then, a period stands out in the record with the highest values of $\delta^{18} \mathrm{O}_{\text {diatom }}$ for the last 4800 years. At $4400 \mathrm{cal} \mathrm{BP}, \delta^{18} \mathrm{O}_{\text {diatom }}$ increases quickly and reaches its maximum value of $31 \%$ o. $\delta^{18} \mathrm{O}_{\text {diatom }}$ remains high (on average $31.3 \%$ o $\pm 0.21 \%$ o between 4400 and $3900 \mathrm{cal}$ BP and decreases, afterwards, to values below those observed at the base of the core. The period from 3900 to $700 \mathrm{cal} \mathrm{BP}$ shows low-amplitude variations in $\delta^{18} \mathrm{O}_{\text {diatom }}$ with an average value of $29.6 \%$ o $\pm 0.13 \%$. After $700 \mathrm{cal} \mathrm{BP}$, the $\delta^{18} \mathrm{O}_{\text {diatom }}$ falls sharply to its lowest value over the study period $(26.6 \%$ at $309 \mathrm{cal} \mathrm{BP})$. In $1986 \mathrm{CE} \delta^{18} \mathrm{O}_{\text {diatom }}$ increases again to reach $27.8 \%$ (Fig. 3a).

The new age-depth model performed with the Bacon $\mathrm{R}$ package is presented in the Supplement Fig. S1. A zoom on the 4800 to 3000 cal BP period is presented in Fig. 3b. Four ${ }^{14} \mathrm{C}$ ages (Fig. 3a) obtained for this time interval, yield an age-depth model precision of ca. 320 years. It supports that at Lake Petit, the $4.2 \mathrm{ka} \mathrm{BP}$ event is actually a 500-year period that occurred from 4400 to $3900 \mathrm{cal} \mathrm{BP}$. According to age uncertainties, the $4.2 \mathrm{ka} \mathrm{BP}$ event cannot be instantaneous in time, and its time range is, at a confidence interval of $95 \%$ of probability, a minimum of 117 years and a maximum of 755 years. 


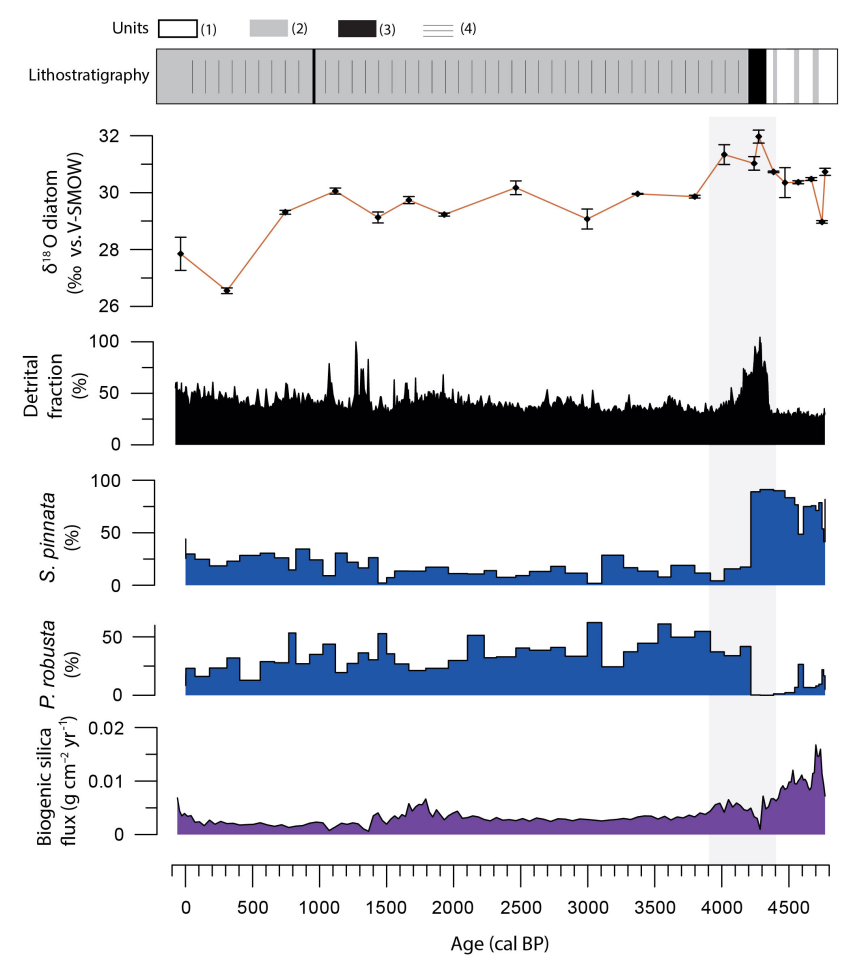

Figure 4. Multi-proxy comparison of environmental responses to the $4.2 \mathrm{kaBP}$ event at Lake Petit including the lithological units (1: pure diatomaceous sediments; 2 : diatomaceous-clay sediments; 3: clay-diatomaceous sediments; 4: diffuse laminations, Brisset et al., 2013), oxygen isotope measurements on diatoms $\left(\delta^{18} \mathrm{O}\right.$ diatom, $\%$ vs. V-SMOW; this study), the detrital fraction ( $\%$ dry weight; Brisset et al., 2013), biogenic silica fluxes $\left(\mathrm{g} \mathrm{cm}^{2} \mathrm{yr}\right)$ and dominant diatom species (relative abundance (\%) of Staurosirella Pinnata, Pseudostaurosira robusta) (Cartier et al., 2015).

\section{Discussion}

The 4400 to $3900 \mathrm{cal} \mathrm{BP} \delta^{18} \mathrm{O}_{\text {diatom values are about } 3 \% \text { 。 }}$ higher than the modern ones $(27.8 \%$ in $1986 \mathrm{CE})$ and correspond to a $1.6 \%$ increase from 4800 to $4400 \mathrm{cal} \mathrm{BP}$ and a $1.5 \%$ decrease from $3900 \mathrm{cal}$ BP. Figure 4 shows that the high $\delta^{18} \mathrm{O}_{\text {diatom }}$ period is contemporaneous with the detrital pulse followed by a shift in diatom species previously evidenced (Brisset et al., 2013; Cartier et al., 2015). This suggests the occurrence of a climatic pulse that impacted the whole catchment. This climatic pulse can be further characterized by comparing the $\delta^{18} \mathrm{O}_{\text {diatom }}$ signal to the present isotope composition of the lake water $\left(\delta^{18} \mathrm{O}_{\text {lake water }}\right)$ and by assessing the physical parameters possibly responsible for an increase in $\delta^{18} \mathrm{O}_{\text {diatom. }}$.
Table 1. Oxygen isotope measurements in diatoms (in \%o vs. VSMOW) for the core PET09P2.

\begin{tabular}{lrrrr}
\hline Sample & Depth $(\mathrm{cm})$ & Age (cal BP) & $\delta^{18} \mathrm{O}_{\text {diatom }}$ & SD \\
\hline PET2.5 & 2.5 & -36 & 27.85 & 0.58 \\
PET13 & 13 & 309 & 26.55 & 0.10 \\
PET 21.5 & 21.5 & 744 & 29.31 & 0.07 \\
PET29 & 29 & 1118 & 30.06 & 0.11 \\
PET37 & 37 & 1436 & 29.13 & 0.19 \\
PET45 & 45 & 1666 & 29.74 & 0.12 \\
PET55 & 55 & 1930 & 29.23 & 0.05 \\
PET68 & 68 & 2464 & 30.17 & 0.24 \\
PET78 & 78 & 2996 & 29.07 & 0.35 \\
PET85 & 85 & 3372 & 29.96 & 0.02 \\
PET94 & 94 & 3798 & 29.86 & 0.05 \\
PET100 & 100 & 4018 & 31.34 & 0.35 \\
PET108 & 108 & 4241 & 31.03 & 0.24 \\
PET109.5 & 109.5 & 4275 & 31.97 & 0.23 \\
PET115 & 115 & 4386 & 30.73 & 0.03 \\
PET120 & 120 & 4471 & 30.35 & 0.52 \\
PET127 & 127 & 4570 & 30.36 & 0.05 \\
PET135 & 135 & 4667 & 30.48 & 0.05 \\
PET142 & 142 & 4747 & 28.97 & 0.05 \\
PET144 & 144 & 4770 & 30.73 & 0.12 \\
\hline
\end{tabular}

\subsection{Present $\delta^{18} \mathrm{O}_{\text {lake water }}$}

The hydrological regime of Lake Petit alternates between two states: an open system when the outlet is active during snowmelt and a closed system during the remaining time. The 2011 one-off $\delta^{18} \mathrm{O}_{\text {lake water measurements indicate that }}$ from the beginning of the frost-free season to the end, the lake water gets heavier by $1.1 \%$. The decrease in water depth at the same time can be interpreted as a signal of evaporation. However, in the $\delta \mathrm{D}$ vs. $\delta^{18} \mathrm{O}$ diagram presented in Fig. $2 \mathrm{a}$, the lake water samples plot on the global meteoric water line, which suggests that evaporation has a limited effect on $\delta^{18} \mathrm{O}_{\text {lake water. }}$. The $1.1 \%$ shift may rather be explained by the drastic decrease in meltwater input at the end of spring. The oxygen isotope composition of meltwater fed by winter precipitation is expected to be lower than $\delta^{18} \mathrm{O}_{\text {precipitation }}$ during summer, due to its Atlantic origin and the low temperature at which snow forms. Post-depositional fractionating processes affecting the snow (including evaporation, sublimation, ablation, meltwater percolation and drifting) that may lead to ${ }^{18} \mathrm{O}$ enrichment of meltwater are likely limited. Indeed, the Lake Petit catchment is small and located under the mountain crest without any glacier supplying the watershed (Stichler and Schotterer, 2000). The seasonal shift occurring today in $\delta^{18} \mathrm{O}_{\text {lake water }}$ has a similar amplitude as the $\delta^{18} \mathrm{O}_{\text {diatom }}$ shift at $4200 \mathrm{cal} \mathrm{BP}$, which suggests similar controls. 


\subsection{Paleo-climatic interpretation of the $\delta^{18} \mathrm{O}_{\text {diatom }}$ record}

Diatom blooms in alpine lakes occur mainly after the snowmelt in spring and during autumn. However, sediment traps placed in a lake in Switzerland located at $2339 \mathrm{~m}$ a.s.l. provide evidence that some diatom species (e.g. Achnanthes, Fragilaria spp.) can continue to grow under the ice when the lake is frozen (Rautio et al., 2000; Lotter and Bigler, 2000). With the omnipresence of Fragilaria spp. in the sedimentary record and the absence of any detailed dynamic of the population over the year, the isotope signal from Lake Petit is considered to be an annual signal mostly influenced by diatoms growing during the ice-free season.

The polymerization of the siliceous frustule from the lake water occurs at equilibrium and the resulting isotope fractionation is thus thermo-dependent. The equilibrium fractionation coefficient previously measured for different silicawater couples range from $-0.2 \%{ }^{\circ} \mathrm{C}^{-1}$ to $-0.4 \%{ }^{\circ} \mathrm{C}^{-1}$ (synthesis in Alexandre et al., 2012; Sharp et al., 2016). According to this range, if the $1.6 \%$ positive shift in $\delta^{18} \mathrm{O}_{\text {diatom }}$ around $4400 \mathrm{cal} \mathrm{BP}$ was only controlled by the lake water temperature change, this would require a negative shift in water temperature of 4 to $8^{\circ} \mathrm{C}$ during the ice-free season, when most of diatoms grow. A very high contribution of snowmelt water may lead to a drastic decrease in the lake water temperature. However, snowmelt is fed by winter precipitation that is ${ }^{18} \mathrm{O}$ depleted, which would counterbalance the effect of low water temperature on $\delta^{18} \mathrm{O}_{\text {diatom. }}$.

Air cooling during the ice-free season may also be invoked. Air cooling during the $4.2 \mathrm{kaBP}$ event in response to a positive North Atlantic Oscillation (NAO) was previously suggested for central Italy (Isola et al., 2019). In the Alps, moraine dating showed moderate glacier advances in northern and western Alps but not in the Mediterranean Alps (Federici and Stefanini, 2001; Ribolini et al., 2007; Ivy-Ochs et al., 2009; Le Roy, 2012, 2017; Brisset et al., 2015). The recent synthesis of Bini et al. (2018) for the Mediterranean region also suggests a possible cooling anomaly at some sites but temperature data are sparse and not uniform. Moreover, the reconstruction of temperature based on chironomids and pollen assemblages from the Swiss Alps and Europe suggest that air temperature variations (likely larger than water temperature variations) did not exceed $2{ }^{\circ} \mathrm{C}$ during the Holocene (Davis et al., 2003; Heiri et al., 2003). At the very least, a decrease in air temperature would decrease $\delta^{18} \mathrm{O}_{\text {precipitation }}$ and $\delta^{18} \mathrm{O}_{\text {lake water }}$ during the ice-free period, which would counterbalance the temperature effect on $\delta^{18} \mathrm{O}_{\text {diatom. Therefore, }}$ a decrease in air and/or lake water temperature cannot be referred to as the dominant control on the increase in $\delta^{18} \mathrm{O}_{\text {diatom }}$ over the 4400-3900 cal period.

An increase in the contribution of ${ }^{18} \mathrm{O}$-enriched Mediterranean precipitation during the ice-free season or, inversely, a decrease in the contribution of ${ }^{18} \mathrm{O}$-depleted Atlantic winter precipitation (due to a winter snow deficit) to the lake water may explain an increase in $\delta^{18} \mathrm{O}_{\text {lake water }}$ at Lake Petit around $4400 \mathrm{cal}$ BP. The other proxies analysed from the studied core instead support the first hypothesis as developed below.

From 4800 to $4350 \mathrm{cal}$ BP, low detrital supply and high chemical weathering suggest the presence of developed acid soils on the catchment slopes (Brisset et al., 2013). From 4350 to 4000 , a maximum of clay detrital supply highlights the dismantling of the former developed weathered soils. The sediments deposited during this period are characterized by high terrigenous fluxes, while the diatom-organic component drops to lower but still significant concentrations $(20 \%)$. Added to the over-representation of low-dispersal alpine meadow plants, these features argue for an intensification of runoff on the catchment slopes during the ice-free season (Brisset et al., 2013; our Fig. 4). For the same period, high percentages of grassland pollen were recorded in Lake Grenouilles (southern Alps) located close to Lake Petit (Kharbouch, 2000), and detrital events occurred at other sites of the Alps, for example at Lake Bourget (Arnaud et al., 2005, 2012). In addition, a cluster of landslide events was identified in the southern Alps around 4200 cal BP (Zerathe et al., 2014). All these features suggest that runoff intensified in the southern Alps around 4200 cal BP, likely due to increasing intense precipitation events, today occurring in autumn (Llasat et al., 2010). At a broader scale, records are less in agreement. Reconstructions of past lake levels suggest wetter conditions from 4500 to $3000 \mathrm{cal} \mathrm{BP}$ at Lake St-Léger (Alpes-de-Haute-Provence; Digerfeldt et al., 1997), Lake Ledro (southern Alps) and Lake Accesa (central Italy) (Magny et al., 2013) (Fig. 5). A high lake level was also reconstructed at Lake Cerin (Jura massif). However, by contrast, a trend towards aridification has been suggested at Lake Preola in Sicily (Magny et al., 2012) or at Renella and Corchia caves in Italy (Drysdale et al., 2006; Zanchetta et al., 2016) (Fig. 5).

A winter snow deficit might have been superimposed on an increase in intense precipitation events during the ice-free season at Lake Petit. In the Italian Apennine, oxygen isotope records from speleothems at Corchia Cave suggested a reduced water cave recharge from ca. 4500 to $4100 \mathrm{cal} \mathrm{BP}$ (Isola et al., 2019). This was interpreted as a weakening of the cyclone centre located in the Gulf of Genoa in response to reduced advection of air masses from the Atlantic during winter.

At the very least, evaporation higher than the modern one may also be considered to explain the ${ }^{18} \mathrm{O}$ enrichment of the Lake Petit water around 4.2 cal BP. However, at a yearly scale, the effect of the previous summer's evaporation is expected to be partially or (greatly) offset by the runoff from snowmelt (Ito et al., 1998), the same as may happen today. Moreover, this would contradict the assumption of a higher precipitation amount during the ice-free season.

In summary, at Lake Petit, the high $\delta^{18} \mathrm{O}_{\text {lake water values }}$ recorded from 4400 to 3900 cal BP support an increase in intense ${ }^{18} \mathrm{O}$-enriched Mediterranean precipitation events dur- 


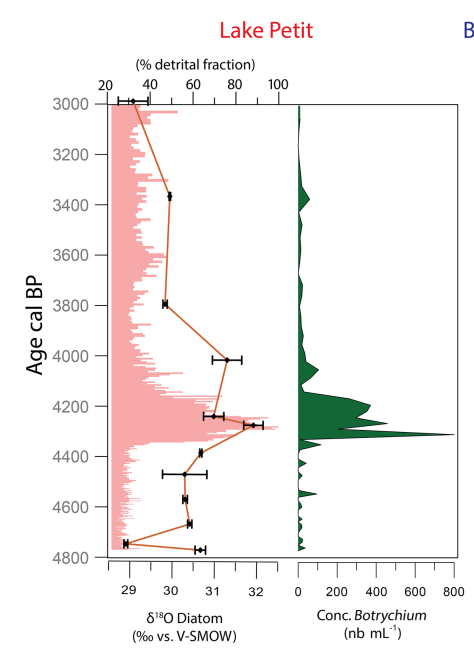

Buca della Renella

Lake Accesa
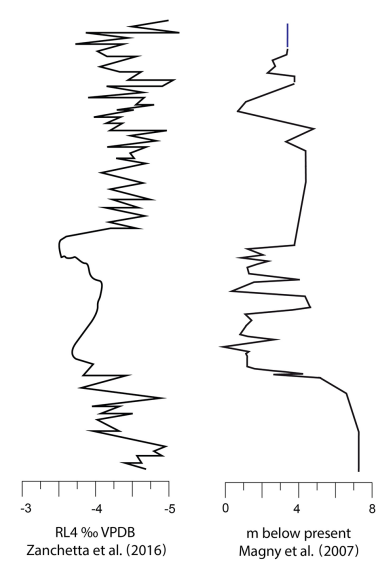

Figure 5. Oxygen isotope measurements in diatoms $\left(\delta^{18} \mathrm{O}_{\text {diatoms }}\right.$ $\%$ vs. V-SMOW; this work), detrital fraction (\%) and conc. (concentration in pollen of) Botrychium (nb mL ${ }^{-1}$ ) (Brisset et al., 2015) at Lake Petit compared to the palaeoclimatic record from the RL4 flowstone at Buca della Renella expressed in per mil with reference to Vienna Pee Dee Belemnite (VPDB) standard (northern Italy, Zanchetta et al., 2016) and Lake level at Accesa (central Italy, Magny et al., 2007).

ing the ice-free season, in agreement with other proxies from the same core and other records from the southern Alps. A reduction in snow may have been superimposed. However, additional evidence is needed to further assess this hypothesis.

At $3900 \mathrm{cal} \mathrm{BP}, \delta^{18} \mathrm{O}_{\text {diatom }}$ values decreased and remained relatively constant for 3300 years during the neoglacial period. Although the low resolution of the record limits the determination of short-term events, a $2.7 \%$ decrease in the $\delta^{18} \mathrm{O}_{\text {diatom }}$ values can be identified around $310 \mathrm{cal} \mathrm{BP}$ (Fig. 3a). This is concomitant with a strong decrease in $\delta^{18} \mathrm{O}$ measured on ostracods from Lake Allos sediments (Cartier, 2016), suggesting regional climate change. Conversely to what may have happened during the time interval 4400-3900 cal BP, an increase in snowmelt contributing to the lake may have triggered a decrease in $\delta^{18} \mathrm{O}_{\text {lake water }}$ and $\delta^{18} \mathrm{O}_{\text {diatom. }}$. This time span falls within the Little Ice Age (450-50 cal BP). The Little Ice Age is recorded as a cold and humid period in the southern Alps as shown in treering records (Corona et al., 2010), fluvial activity reconstructions (Miramont et al., 1998) and glacial tongue advances (Holzhauser et al., 2005; Ivy-ochs et al., 2009). These records are thus in agreement with an increase in snowmelt water contribution to Lake Petit.

\section{Conclusions}

The location of Lake Petit above the local tree line, at the head of a small Alpine watershed, as well as its semi-closed lacustrine system lead to the high responsiveness of the lake to changes in precipitation regime. Thanks to a robust and accurate age model, the last 4800 -year $\delta^{18} \mathrm{O}_{\text {diatom }}$ record allowed us to identify a 500-year time lapse, from 4400 to $3900 \mathrm{cal} \mathrm{BP}$, where $\delta^{18} \mathrm{O}_{\text {diatom }}$ reached its highest values. This period of high $\delta^{18} \mathrm{O}_{\text {diatom }}$ values can be explained by intense ${ }^{18} \mathrm{O}$-enriched Mediterranean precipitation events feeding the lake during the ice-free season. This agrees with previous reconstructions from the same core (Brisset et al., 2012, 2013) and other records from the southern Alps suggesting runoff intensification around $4200 \mathrm{calBP}$. Possible changes in other climatic parameters may have played a concomitant role, including a decrease in the contribution of ${ }^{18} \mathrm{O}$-depleted Atlantic winter precipitation to the lake water due to snow deficit. However, additional evidence is needed to further assess this hypothesis.

Data recording the $4.2 \mathrm{kaBP}$ event in the north-western Mediterranean area are still sparse. In the Lake Petit watershed, a climatic pulse translated into a change in precipitation regime occurred from 4400 to $3900 \mathrm{cal}$ BP. This record contributes to the recent efforts to characterize and investigate the geographical extent of the $4.2 \mathrm{ka} \mathrm{BP}$ event in the Mediterranean area.

Data availability. Oxygen isotopes values are presented in this paper. The age-depth model is available in the Supplement. Radiocarbon ages are already published in the journal The Holocene as Brisset et al. (2013): https://doi.org/10.1177/0959683613508158.

Supplement. The supplement related to this article is available online at: https://doi.org/10.5194/cp-15-253-2019-supplement.

Author contributions. RC wrote the manuscript and performed analysis with FS. CP, FG and CM provided funding support and material. AA, EB and FG helped improve the manuscript. CS, MC and JCM worked on analysing samples. All co-authors gave their comments and agreement during the writing process.

Competing interests. The authors declare that they have no conflict of interest.

Special issue statement. This article is part of the special issue "The $4.2 \mathrm{ka} \mathrm{BP}$ climatic event". It is a result of "The $4.2 \mathrm{ka} \mathrm{BP}$ Event: An International Workshop", Pisa, Italy, 10-12 January 2018.

Acknowledgements. This work was supported by the ECCOREV research federation (HOMERE program led by Frédéric Guiter and Christine Paillès). The PhD thesis work of Rosine Cartier 
(Aix-Marseille University) was funded by the French Ministry of Education.

We thank Christine Vallet-Coulomb (CEREGE, France) for the isotope analysis of modern Lake Petit waters and Pauline Chaurand (CEREGE, France) for providing help with the micro-XRF measurements. Thanks to Alain Tonetto (Aix-Marseille University) for managing the SEM in Marseille. Coring of Lake Petit (in 2009 and 2012) was made possible thanks to Fabien Arnaud (EDYTEM), Charline Giguet-Covex (EDYTEM), Emmanuel Malet (EDYTEM), Johan Pansu (Princeton University), Jérome Poulenard (EDYTEM) and Bruno Wilhelm (LTHE).

Edited by: Giovanni Zanchetta

Reviewed by: two anonymous referees

\section{References}

Alexandre, A., Basile-Doelsch, I., Sonzogni, C., Sylvestre, F., Parron, C., Meunier, J. D., and Colin, F.: Oxygen isotope analyses of fine silica grains using laser-extraction technique: Comparison with oxygen isotope data obtained from ion microprobe analyses and application to quartzite and silcrete cement investigation, Geochim. Cosmochim. Ac., 70, 2827-2835, 2006.

Alexandre, A., Crespin, J., Sylvestre, F., Sonzogni, C., and Hilbert, D. W.: The oxygen isotopic composition of phytolith assemblages from tropical rainforest soil tops (Queensland, Australia): validation of a new paleoenvironmental tool, Clim. Past, 8, 307324, https://doi.org/10.5194/cp-8-307-2012, 2012.

Alley, R. B., Mayewski, P. A., Sowers, T., Stuiver, M., Taylor, K. C., and Clark, P. U.: Holocene climatic instability: A prominent, widespread event 8200 yr ago, Geology, 25, 483-486, 1997.

Arnaud, F., Revel, M., Chapron, E., Desmet, M., and Tribovillard, N.: 7200 years of Rhone river flooding activity in Lake Le Bourget, France: a high-resolution sediment record of NW Alps hydrology, The Holocene, 15, 420-428, 2005.

Arnaud, F., Révillon, S., Debret, M., Revel, M., Chapron, E., Jacob, J., Giguet-Covex, C., Poulenard, J., and Magny, M.: Lake Bourget regional erosion patterns reconstruction reveals Holocene NW European Alps soil evolution and paleohydrology, Quaternary Sci. Rev., 51, 81-92, 2012.

Barker, P. A., Street-Perrott, F. A., Leng, M. J., Greenwood, P. B., Swain, D. L., Perrott, R. A., Telford, P. J., and Ficken, K. J.: A 14,000-year oxygen isotope record from diatom silica in two alpine lakes on Mt. Kenya, Science, 292, 2307-2310, 2001.

Berger, J. F. and Guilaine, J.: The 8200 cal. BP abrupt environmental change and the Neolithic transition: A Mediterranean perspective, Quatern. Int., 200, 31-49, 2009.

Bini, M., Zanchetta, G., Persoiu, A., Cartier, R., Català, A., Cacho, I., Dean, J. R., Di Rita, F., Drysdale, R. N., Finnè, M., Isola, I., Jalali, B., Lirer, F., Magri, D., Masi, A., Marks, L., Mercuri, A. M., Peyron, O., Sadori, L., Sicre, M.-A., Welc, F., Zielhofer, C., and Brisset, E.: The $4.2 \mathrm{kaBP}$ Event in the Mediterranean Region: an overview, Clim. Past Discuss., https://doi.org/10.5194/cp-2018-147, in review, 2018.

Blaauw, M. and Christen, J. A.: Flexible paleoclimate age-depth models using an autoregressive gamma process, Bayesian Anal., 6, 457-474, 2011.
Bolle, H. J.: Climate, climate variability, and impacts in the Mediterranean area: an overview, in: Mediterranean Climate, 5-86, Springer, Berlin, Heidelberg, 2003.

Bond, G., Showers, W., Cheseby, M., Lotti, R., Almasi, P., deMenocal, P., Priore, P., Cullen, H., Hajdas, I., and Bonani, G.: A Pervasive Millennial-Scale Cycle in North Atlantic Holocene and Glacial Climates, Science, 278, 1257-1266, 1997.

Booth, R. K., Jackson, S. T., Forman, S. L., Kutzbach, J. E., Bettis, E. A., Kreigs, J., and Wright, D. K.: A severe centennial-scale drought in midcontinental North America 4200 years ago and apparent global linkages, The Holocene, 15, 321-328, 2005.

Brauer, A., Endres, C., Günter, C., Litt, T., Stebich, M., and Negendank, J. F. W.: Highresolution sediment and vegetation responses to Younger Dryas climate change in varved lake sediments from Meerfelder Maar, Germany, Quaternary Sci. Rev., 18, 321-329, 1999.

Brisset, E., Guiter, F., Miramont, C., Delhon, C., Arnaud, F., Disnar, J. R., Poulenard, J., Anthony, E., Meunier, J. D., Wilhelm, B., and Paillès, C.: Approche multidisciplinaire d'une séquence lacustre holocène dans les alpes du sud au Lac Petit (Mercantour, alt. 2 200 m, France)?, histoire d'un géosystème dégradé, Quaternaire, Revue de l'Association française pour l'étude du Quaternaire, 23, 309-319, 2012.

Brisset, E., Miramont, C., Guiter, F., Anthony, E. J., Tachikawa, K., Poulenard, J., Arnaud, F., Delhon, C., Meunier, J. D., Bard, E., and Suméra, F.: Non-reversible geosystem destabilisation at $4200 \mathrm{cal}$. BP: Sedimentological, geochemical and botanical markers of soil erosion recorded in a Mediterranean alpine lake, The Holocene, 23, 1863-1874, 2013.

Brisset, E., Guiter, F., Miramont, C., Revel, M., Anthony, E. J., Delhon, C., and de Beaulieu, J. L.: Lateglacial/Holocene environmental changes in the Mediterranean Alps inferred from lacustrine sediments, Quaternary Sci. Rev., 110, 49-71, 2015.

Bruneton, H., Provensal, M., Devillers, B., Jorda, C., Ollivier, V., Miramont, C., and Leveau, P.: Relations entre paléohydrologie et morphogenèse holocènes des petits et moyens bassin-versants en basse Provence et Languedoc oriental. Les fleuves ont une histoire: paléo-environnement des rivières et des lacs français depuis 15000 ans, in: Histoire des rivières et des lacs de Lascaux à nos jours, edited by: Bravard, J.-P. and Magny, M. (Dir.), Paris: Errance, 259-267, 2002.

Cartier, R.: Trajectoires des écosystèmes lacustres alpins depuis 13500 ans dans les Alpes méditerranéennes (Massif du Mercantour, France), Ph.D thesis Aix-Marseille University, 235 pp., 2016.

Cartier, R., Brisset, E., Paillès, C., Guiter, F., Sylvestre, F., Ruaudel, F., Anthony, E. J., and Miramont, C.: 5000 years of lacustrine ecosystem changes from Lake Petit (Southern Alps, $2200 \mathrm{~m}$ asl): Regime shift and resilience of algal communities, The Holocene, 25, 1231-1245, 2015.

Celle-Jeanton, H., Travi, Y., and Blavoux, B.: Isotopic typology of the precipitation in the Western Mediterranean region at three different time scales, Geophys. Res. Lett., 28, 1215-1218, 2001.

Celle-Jeanton, H., Gonfiantini, R., Travi, Y., and Sol, B.: Oxygen18 variations of rainwater during precipitation: application of the Rayleigh model to selected rainfalls in Southern France, J. Hydrol., 289, 165-177, 2004.

Chapligin, B., Meyer, H., Friedrichsen, H., Marent, A., Sohns, E., and Hubberten, H. W.: A high-performance, safer and semi- 
automated approach for the $\delta 180$ analysis of diatom silica and new methods for removing exchangeable oxygen, Rapid Commun. Mass Spect., 24, 2655-2664, 2010.

Corona, C., Guiot, J., Edouard, J. L., Chalié, F., Büntgen, U., Nola, P., and Urbinati, C.: Millennium-long summer temperature variations in the European Alps as reconstructed from tree rings, Clim. Past, 6, 379-400, https://doi.org/10.5194/cp-6-379-2010, 2010.

Crespin, J., Alexandre, A., Sylvestre, F., Sonzogni, C., Pailles, C., and Garreta, V.: IR laser extraction technique applied to oxygen isotope analysis of small biogenic silica samples, Anal. Chem., 80, 2372-2378, 2008.

Cullen, H. M., deMenocal, P. B., Hemming, S., Hemming, G., Brown, F. H., Guilderson, T., and Sirocko, F.: Climate change and the collapse of the Akkadian empire: Evidence from the deep sea, Geology, 28, 379-382, 2000.

Davis, B. A., Brewer, S., Stevenson, A. C., and Guiot, J.: The temperature of Europe during the Holocene reconstructed from pollen data, Quaternary Sci. Rev., 22, 1701-1716, 2003.

Dean, J. R., Jones, M. D., Leng, M. J., Noble, S. R., Metcalfe, S. E., Sloane, H. J., Sahy, D., Eastwood, W. J., and Roberts, C. N.: Eastern Mediterranean hydroclimate over the late glacial and Holocene, reconstructed from the sediments of Nar lake, central Turkey, using stable isotopes and carbonate mineralogy, Quaternary Sci. Rev., 124, 162-174, 2015.

Digerfeldt, G., de Beaulieu, J. L., Guiot, J., and Mouthon, J.: Reconstruction and paleoclimatic interpretation of Holocene lakelevel changes in Lac de Saint-Léger, Haute-Provence, southeast France, Palaeogeogr. Palaeocl., 136, 231-258, 1997.

Dodd, J. P., Wiedenheft, W., and Schwartz, J. M.: Dehydroxylation and diagenetic variations in diatom oxygen isotope values, Geochim. Cosmochim. Ac., 199, 185-195, 2017.

Drysdale, R., Zanchetta, G., Hellstrom, J., Maas, R., Fallick, A., Pickett, M., Cartwright, I., and Piccini, L.: Late Holocene drought responsible for the collapse of Old World civilizations is recorded in an Italian cave flowstone, Geology, 34, 101-104, 2006.

Durand, Y., Giraud, G., Laternser, M., Etchevers, P., Mérindol, L., and Lesaffre, B.: Reanalysis of 47 Years of Climate in the French Alps (1958-2005): Climatology and Trends for Snow Cover, J. Appl. Meteorol. Climatol., 48, 2487-2512, 2009a.

Durand, Y., Laternser, M., Giraud, G., Etchevers, P., Lesaffre, B., and Mérindol, L.: Reanalysis of $44 \mathrm{Yr}$ of Climate in the French Alps (1958-2002): Methodology, Model Validation, Climatology, and Trends for Air Temperature and Precipitation, J. Appl. Meteorol. Climatol., 48, 429-449, 2009b.

Federici, P. R. and Stefanini, M. C.: ABHANDLUNGEN-Evidence and chronology of the Little Ice Age in the Argentera Massif (italian maritime alps). With 7 figures, Z. Gletscherk. Glazial., 37, 35-48, 2001.

Heiri, O., Lotter, A. F., Hausmann, S., and Kienast, F.: A chironomid-based Holocene summer air temperature reconstruction from the Swiss Alps, The Holocene, 13, 477-484, 2003.

Holzhauser, H., Magny, M., and Zumbuühl, H. J.: Glacier and lakelevel variations in west-central Europe over the last 3500 years, The Holocene 15, 789-801, 2005.

Huang, C. C., Pang, J., Zha, X., Su, H., and Jia, Y.: Extraordinary floods related to the climatic event at $4200 \mathrm{cal}$. BP on the Qishuihe River, middle reaches of the Yellow River, China, Quaternary Sci. Rev., 30, 460-468, 2011.
IAEA/WMO: Global Network of Isotopes in Precipitation. The GNIP Database, available at: http://www.iaea.org/water (last access: December 2018), 2018.

Isola, I., Zanchetta, G., Drysdale, R. N., Regattieri, E., Bini, M., Bajo, P., Hellstrom, J. C., Baneschi, I., Lionello, P., Woodhead, J., and Greig, A.: The $4.2 \mathrm{ka}$ event in the central Mediterranean: new data from a Corchia speleothem (Apuan Alps, central Italy), Clim. Past, 15, 135-151, https://doi.org/10.5194/cp15-135-2019, 2019.

Ito, E., Yu, Z., Engstrom, D. R., and Fritz, S. C.: Is paleoclimatic interpretation of oxygen isotope records from glaciated Great Plains possible, Abstracts, AMQUA, 15, p. 119, 1998.

Ivy-Ochs, S., Kerschner, H., Maisch, M., Christl, M., Kubik, P. W., and Schlüchter, C.: Latest Pleistocene and Holocene glacier variations in the European Alps, Quaternary Sci. Rev., 28, 2137 2149, 2009.

Kharbouch, M.: L'homme et la veìgeìtation dans la reìgion du mont Bego (Tende, Alpes-Maritimes) depuis des milleìnaires. Comptes Rendus de l'Acadeìmie des Sciences - Series IIA, Earth. Planet. Sci., 330, 889-894, 2000.

Llasat, M. C., Llasat-Botija, M., Prat, M. A., Porcú, F., Price, C., Mugnai, A., Lagouvardos, K., Kotroni, V., Katsanos, D., Michaelides, S., Yair, Y., Savvidou, K., and Nicolaides, K.: High-impact floods and flash floods in Mediterranean countries: the FLASH preliminary database, Adv. Geosci., 23, 47-55, https://doi.org/10.5194/adgeo-23-47-2010, 2010.

Leng, M. J. and Barker, P. A.: A review of the oxygen isotope composition of lacustrine diatom silica for palaeoclimate reconstruction, Earth-Sci. Rev., 75, 5-27, 2006.

Le Roy, M.: Reconstitution des fluctuations glaciaires holocènes dans les Alpes occidentales: apports de la dendrochronologie et de la datation par isotopes cosmogéniques produits in situ, Diss. Grenoble, 2012.

Le Roy, M., Deline, P., Carcaillet, J., Schimmelpfennig, I., Ermini, M., and ASTER Team: ${ }^{10} \mathrm{Be}$ exposure dating of the timing of Neoglacial glacier advances in the Ecrins-Pelvoux massif, southern French Alps, Quaternary Sci. Rev., 178, 118-138, 2017.

Lionello, P., Bhend, J., Buzzi, A., Della-Marta, P. M., Krichak, S. O., Jansa, A., and Trigo, R.: Cyclones in the Mediterranean region: climatology and effects on the environment, in: Developments in earth and environmental sciences, Vol. 4, 325-372, edited by: Elsevier, 2006 and Lionello, P.: The climate of the Mediterranean region: From the past to the future, Elsevier, 2012.

Lotter, A. F. and Bigler, C.: Do diatoms in the Swiss Alps reflect the length of ice-cover?, Aqua. Sci., 62, 125-141, 2000.

Magny, M., De Beaulieu, J. L., Drescher-Schneider, R., Vannière, B., Walter-Simonnet, A. V., Miras, Y., and Leroux, A.: Holocene climate changes in the central Mediterranean as recorded by lakelevel fluctuations at Lake Accesa (Tuscany, Italy), Quaternary Sci. Rev., 26, 1736-1758, 2007.

Magny, M., Vannière, B., Zanchetta, G., Fouache, E., Touchais, G., Petrika, L., Croussot, C., Walter-Simonnet, A. V., and Arnaud, F.: Possible complexity of the climatic event around 4300$3800 \mathrm{cal}$. BP in the central and western Mediterranean, The Holocene, 19, 823-833, 2009.

Magny, M., Joannin, S., Galop, D., Vannière, B., Haas, J. N., Bassetti, M., Bellintani, P., Scandolari, R., and Desmet, M.: Holocene palaeohydrological changes in the northern Mediter- 
ranean borderlands as reflected by the lake-level record of Lake Ledro, northeastern Italy, Quatern. Res., 77, 382-396, 2012.

Magny, M., Combourieu-Nebout, N., de Beaulieu, J. L., BoutRoumazeilles, V., Colombaroli, D., Desprat, S., Francke, A., Joannin, S., Ortu, E., Peyron, O., Revel, M., Sadori, L., Siani, G., Sicre, M. A., Samartin, S., Simonneau, A., Tinner, W., Vannière, B., Wagner, B., Zanchetta, G., Anselmetti, F., Brugiapaglia, E., Chapron, E., Debret, M., Desmet, M., Didier, J., Essallami, L., Galop, D., Gilli, A., Haas, J. N., Kallel, N., Millet, L., Stock, A., Turon, J. L., and Wirth, S.: North-south palaeohydrological contrasts in the central Mediterranean during the Holocene: tentative synthesis and working hypotheses, Clim. Past, 9, 20432071, https://doi.org/10.5194/cp-9-2043-2013, 2013.

Miramont, C., Jorda, M., and Pichard, G.: Évolution historique de la morphogenèse et de la dynamique fluviale d'une rivière méditerranéenne?, l'exemple de la moyenne durance (France du sud-est), Géogr. Phys. Quatern., 52, 381-392, 1998.

Miramont, C., Boutterin, C., Sivan, O., Bruneton, H., and Mantran, M.: Grandes seìquences et principales ruptures morphogeìniques en haute Provence les complexes seìdimentaires des petits organismes torrentiels de moyenne Durance, Cahiers de Paleìoenvironnement (Collection Edytem), 145-154, 2008.

Peyron, O., Magny, M., Goring, S., Joannin, S., de Beaulieu, J.L., Brugiapaglia, E., Sadori, L., Garfi, G., Kouli, K., Ioakim, C., and Combourieu-Nebout, N.: Contrasting patterns of climatic changes during the Holocene across the Italian Peninsula reconstructed from pollen data, Clim. Past, 9, 1233-1252, https://doi.org/10.5194/cp-9-1233-2013, 2013.

Quesada, B., Sylvestre, F., Vimeux, F., Black, J., Pailles, C., Sonzogni, C., Alexandre, A., Blard, P. H., Tonetto, A., Mazur, J. C., and Bruneton, H.: Impact of Bolivian paleolake evaporation on the $\delta^{18} \mathrm{O}$ of the Andean glaciers during the last deglaciation $(18.5-11.7 \mathrm{ka})$ : diatom-inferred $\delta^{18} \mathrm{O}$ values and hydro-isotopic modeling, Quaternary Sci. Rev., 120, 93-106, 2015.

Rautio, M., Sorvari, S., and Korhola, A.: Diatom and crustacean zooplankton communities, their seasonal variability and representation in the sediments of subarctic Lake Saanajärvi, J. Limnol., 59, 81-96, 2000.

Ribolini, A., Chelli, A., Guglielmin, M., and Pappalardo, M.: Relationships between glacier and rock glacier in the Maritime Alps, Schiantala Valley, Italy, Quaternary Res., 68, 353-363, 2007.

Sharp, Z. D., Gibbons, J. A., Maltsev, O., Atudorei, V., Pack, A., Sengupta, S., and Knauth, L. P.: A calibration of the triple oxygen isotope fractionation in the $\mathrm{SiO}_{2}-\mathrm{H}_{2} \mathrm{O}$ system and applications to natural samples, Geochim. Cosmochim. Acta, 186, 105-119, 2016.
Staubwasser, M., Sirocko, F., Grootes, P. M., and Segl, M.: Climate change at the $4.2 \mathrm{ka}$ BP termination of the Indus valley civilization and Holocene south Asian monsoon variability, Geophys. Res. Lett., 30, 1425, https://doi.org/10.1029/2002GL016822, 2003.

Stichler, W. and Schotterer, U.: From accumulation to discharge: modification of stable isotopes during glacial and post-glacial processes, Hydrol. Process., 14, 1423-1438, 2000.

Terzer, S., Wassenaar, L. I., Araguás-Araguás, L. J., and Aggarwal, P. K.: Global isoscapes for $\delta^{18} \mathrm{O}$ and $\delta^{2} \mathrm{H}$ in precipitation: improved prediction using regionalized climatic regression models, Hydrol. Earth Syst. Sci., 17, 4713-4728, https://doi.org/10.5194/hess-17-4713-2013, 2013.

Thompson, L. G., Mosley-Thompson, E., Davis, M. E., Henderson, K. A., Brecher, H. H., Zagorodnov, V. S., Mashiotta, T. A., Lin, P. N., Mikhalenko, V. N., Hardy, D. R., and Beer, J.: Kilimanjaro ice core records: evidence of Holocene climate change in tropical Africa, Science, 298, 589-593, 2002.

Tinner, W. and Lotter, A. F.: Central European vegetation response to abrupt climate change at $8.2 \mathrm{ka}$, Geology, 29, 551-554, 2001.

Walker, M. J. C., Berkelhammer, M., Bj'orck, S., Cwynar, L. C., Fisher, D. A., Long, A. J., Lowe, J. J., Newnham, R. M., Rasmussen, S. O., and Weiss, H.: Formal subdivision of the Holocene series/epoch: a discussion paper by a working group of INTIMATE (integration of ice-core, marine and terrestrial records) and the subcommission on quaternary stratigraphy (international commission on stratigraphy), J. Quat. Sci., 27, 649e659, https://doi.org/10.1002/jqs.2565, 2012.

Weiss, H., Courty, M. A., Wetterstrom, W., Guichard, F., Senior, L., Meadow, R., and Curnow, A.: The genesis and collapse of third millennium north Mesopotamian civilization, Science, 261, 9951004, 1993.

Zanchetta, G., Sulpizio, R., Roberts, N., Cioni, R., Eastwood, W. J., Siani, G., Caron, B., Paterne, M., and Santacroce, R.: Tephrostratigraphy, chronology and climatic events of the Mediterranean basin during the Holocene: An overview, The Holocene, 21, 3352, 2011.

Zanchetta, G., Regattieri, E., Isola, I., Drysdale, R. N., Bini, M., Baneschi, I., and Hellstrom, J. C.: The so-called " 4.2 event" in the central Mediterranean and its climatic teleconnections, Alp. Mediterr. Quat., 29, 5-17, 2016.

Zerathe, S., Lebourg, T., Braucher, R., and Bourlès, D.: MidHolocene cluster of large-scale landslides revealed in the Southwestern Alps by $36 \mathrm{Cl}$ dating. Insight on an Alpine-scale landslide activity, Quaternary Sci. Rev., 90, 106-127, 2014. 